\title{
Obsidian Artifacts from the Ozark Area
}

Don R. Dickson

Unknown

Follow this and additional works at: https://scholarworks.sfasu.edu/ita

Part of the American Material Culture Commons, Archaeological Anthropology Commons, Environmental Studies Commons, Other American Studies Commons, Other Arts and Humanities Commons, Other History of Art, Architecture, and Archaeology Commons, and the United States History Commons

Tell us how this article helped you.

This Article is brought to you for free and open access by the Center for Regional Heritage Research at SFA ScholarWorks. It has been accepted for inclusion in Index of Texas Archaeology: Open Access Gray Literature from the Lone Star State by an authorized editor of SFA ScholarWorks. For more information, please contact cdsscholarworks@sfasu.edu. 


\section{Obsidian Artifacts from the Ozark Area}

Creative Commons License

(c) () () (9)

This work is licensed under a Creative Commons Attribution-NonCommercial 4.0 International License 
Volume 8, Number 4

\title{
Obsidian Artifacts from the Ozark Area
}

\author{
Don R. Dickson
}

In a paper presented at the Ozark Prehistory II session at the Society for American Archaeology meeting in New Orleans in 1996, the author stated that available evidence suggested two possible movements of Plains oriented peoples into the Ozark area during prehistoric times. The first of these was during the Late Archaic, and is reflected in quantities of Hanna, Duncan, and McKean bifaces being found in western Ozark sites. All of these types were named by Wheeler (1954:7; 1952: 45) for examples recovered from Late Archaic sites in Wyoming. Although Perino (1985:166) suggests that the northeastern Oklahoma examples are only similar and should be named something else, all three types are often found on the same site in a Late Archaic context. In addition, the specimens are morphologically the same as Plains examples.

The second apparent influx of Plains oriented peoples into the western Ozark area was during the Late Prehistoric when what is referred to as the Neosho phase suddenly appears in the area. Such Plains traits as Harahey knives, snub nosed scrapers, triangular arrow points, bison bone artifacts, and distinctive punctate decorated shell tempered pottery are found at both village sites and bluff shelters.
Archeologists have yet to relate the Neosho phase phenomena to a specific Plains antecedent population in a convincing way.

Having a deep interest in knappable raw materials and their sources, I was intrigued several years ago when a Siloam Springs collector whom I knew very well handed me an obsidian biface which he had found just west of the Lake Francis dam on the Illinois River. The site involved produced both Archaic and more recent Caddoan artifacts. The collector, now deceased, was totally reliable and gave me the specimen before he passed away. The artifact, illustrated in Figure 1, is a good example of the Duncan type. The stem is bifurcated and the prominent shoulders are sloping. In cross section, the blade is generally lenticular; however, the left margin and the slightly rounded tip are unifacially beveled to some degree. This, plus apparent use wear on these margins, suggest the biface last functioned as a scraper. Length of the biface is $3.9 \mathrm{~cm}$, width is $2.0 \mathrm{~cm}$, and thickness is $0.7 \mathrm{~cm}$. The black obsidian is fairly opaque with translucency being limited to the thinnest edges. At this time, a source for the obsidian has not been determined, although macroscopically it compares favorably with some Idaho 


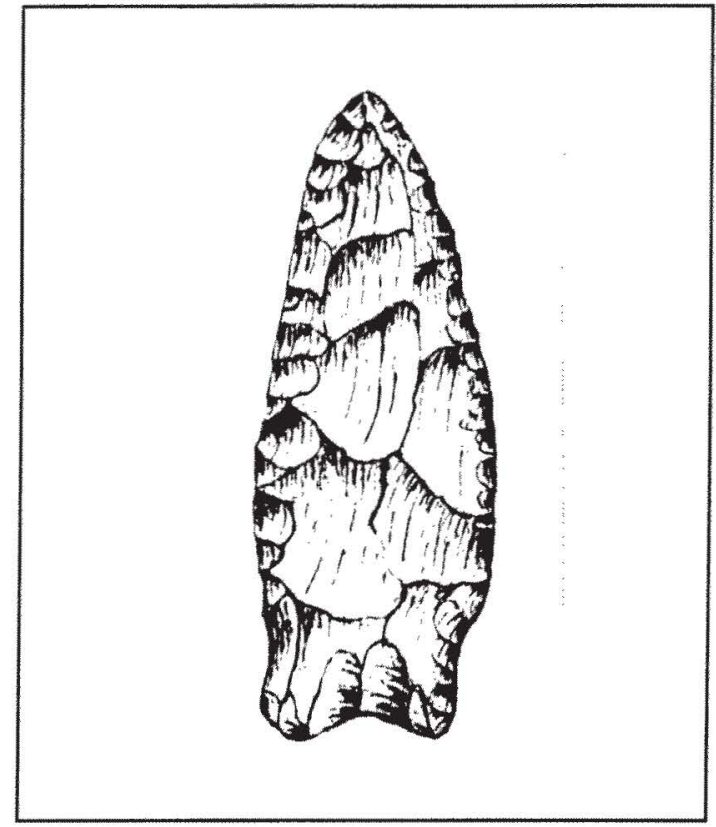

Figure 1. Obsidian Biface from Illinois River, Adair County, Oklahoma, Across from Camp Paddle Trails.

obsidian I have in collections of lithic raw materials.

Many people fail to realize that the Ozark

region extends across the Mississippi into southern Illinois. Another Late Archaic obsidian artifact was reported from just south of the eastern Ozark area in Dunklin County, Missouri in 1954 (Davidson 1954). The biface, apparently resharpened by pressure flaking, features rounded shoulders and a bifurcated hafting area. Typologically, it most closely resembles the Hanna category. The length is $6.5 \mathrm{~cm}$ and width was $2.5 \mathrm{~cm}$. Thickness was not stated in the Missouri Archaeologist article. Figure 2 depicts the biface at actual scale. Source of the obsidian is unknown.

A third obsidian artifact, not illustrated in this brief article, is a pointed obsidian flake apparently used as a perforator. The specimen, found in the $10-20 \mathrm{~cm}$ level adjacent to a Neosho phase house floor at the Brown Bluff site (3WA10) in Washington County, Arkansas, came from beneath a large rock slab and was associated with a substantial root network. While the matrix was thus disturbed considerably, it seems probable that the provenience was Late Prehistoric period, probably Neosho phase (Harcourt 1994: 25). In a personal communication, Dr. Tom Green of the Arkansas Archeological Survey stated that Mr. Richard Hughes had concluded that the obsidian originated in the Malad igneous flow in southeastern Idaho (Green 1998). According to Hughes, this flow was used as a source of obsidian mostly by Late Prehistoric and early historic peoples. Mr. Alan Hawkins, now with Historic Preservation Associates, examined the artifact and stated that it was an example of opaque obsidian with translucence noticeable only on very thin edges. Dimensions of the specimen are not available at this time, but Hawkins (1998) estimated the length at about $2 \mathrm{~cm}$.

Whenever one deals with extremely limited artifact samples, the analyst faces a serious problem in interpretation of these finds. One might explain these few artifacts as reflecting trade from the Plains area or from the southwestern United States. On the other hand, a tentative explanation might be that these few obsidian 


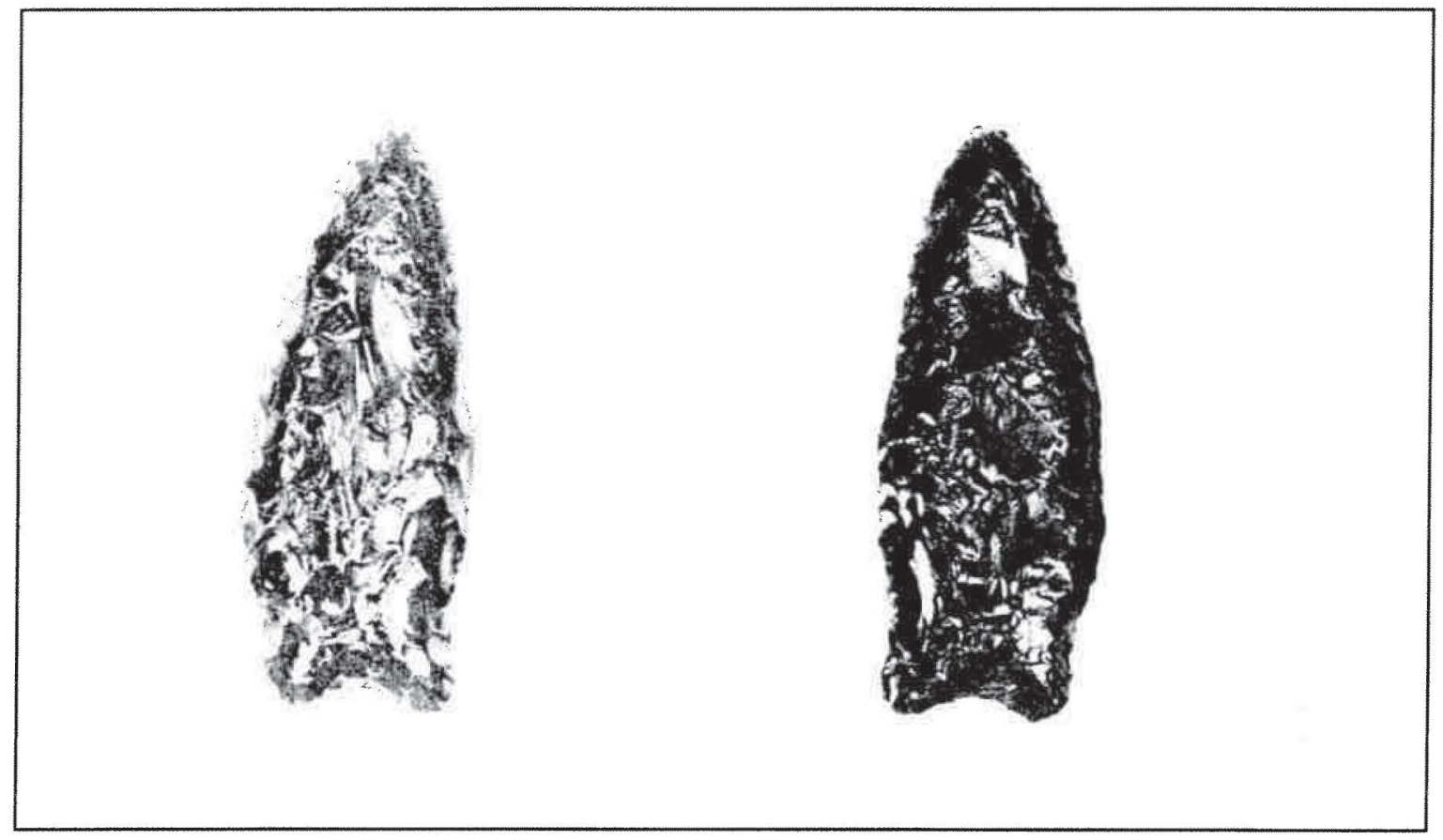

Figure 2. An Obsidian Projectile Point from Dunklin County, Missouri (both faces; adapted from Davidson 1954).

artifacts could have been brought into the Ozark and adjacent areas by late Archaic and Late Prehistoric peoples from the Plains area. Changes in biotic assemblages at Ozark sites suggest a possible reason why Late Archaic hunters may have visited the Ozark area. For example, pronghorn antelope (Antilocapra americana) have been reported from both the Ten Mile Rock site (3WA197) and the Albertson Shelter (3BE174). Medlock (1978) discussed both of these finds. While the situation at Ten Mile Rock was not totally clear, the stratigraphy at Albertson was, and antelope remains were recovered from both Late Middle Archaic and Late Archaic strata. Considering the fact that pronghorn antelope usually reside in prairie or desert habitats, the western Ozark area may have experienced limited rainfall during Late Archaic times. Perhaps more severe drought on the plains caused movements of people from that area into the Ozarks.

While we do not have adequate data today to do more than suggest tentative causes for apparent movements of Plains hunters and agriculturists into the Ozark area, we can become alert to this interesting problem and attempt to ascertain why these interactions took place. It may not be totally coincidental that documented obsidian artifacts seem to relate to components which entered the Ozark area from the Plains. 


\section{References}

Davidson, W.L.

1954 An Obsidian Projectile Point from Southeast Missouri. The Missouri Archaeologist 16(2):35-36.

Green, Thomas

1998 Personal communication at Don R. Dickson, January 5, 1998. Fayetteville, Arkansas.

Harcourt, James P.

1994 A Management Summary for the Step Two Archeological Excavations at the Brown Bluff Site (3WA10), Washington County, Arkansas. Ms. submitted to Arkansas Highway and Transportation Department, Little Rock, Arkansas, by Sponsored Research Program, Arkansas Archeological Survey, Fayetteville.

Hawkins, Alan 1998 Personal communication to Don R.
Dickson, January 5, 1998. Fayetteville, Arkansas.

Medlock, R.C.

1978 Ten Mile Rock: Pigs, Peccaries, and People. The Arkansas Archeologist 19:1-24.

Perino, Gregory

1985 Selected Preforms, Points and Knives of the North American Indians, Volume I. Points and Barbs Press, Idabel, Oklahoma.

Wheeler, Richard P.

1952 A Note on the McKean Lanceolate Point. Plains Archaeological Conference Newsletter 4(4):45.

1954 Two New Projectile Point Types: Duncan and Hanna Points. The Plains Anthropologist 1:7. 